\title{
THE MASTOGLOIA STAGE IN THE BALTIC SEA HISTORY: DIATOM EVIDENCE FROM SOUTHERN FINLAND
}

\author{
HANNU HYVÄRINEN
}

\begin{abstract}
HYVÄRINEN, H., 1984: The Mastogloia stage in the Baltic Sea history: diatom evidence from southern Finland. Bull. Geol. Soc. Finland 56, Part 1-2, 99-115. Studies of ancient Baltic sediments obtained from isostatically uplifted lake basins near Helsinki, on the south coast of Finland, have yielded diatom sequences across the transition from Ancylus Lake to Litorina Sea strata. Different facies within the general near-shore environment, from shallow littoral to moderately deep $(10-20 \mathrm{~m})$ open bay, are represented. All the sediments deposited before 8000 B.P. contain oligohalobous diatom floras normally associated with the Ancylus Lake stage. Between 8000 and 7500 B.P., an interval often singled out as the Mastogloia stage, weakly brackish taxa are regularly introduced into the strictly littoral floras, whereas the floras deposited at the same time in deeper water remain unchanged and consist of ordinary Ancylus taxa. After 7500 B.P. rich brackish floras characteristic of the Litorina stage proper appear at all sites that retained their contact with the Baltic.

These results confirm the earlier conclusions based on off-shore data that the Mastogloia stage can only be demonstrated in the littoral facies. Nevertheless, in view of its consistent and non-local occurrence after but not before a certain time point, this stage is considered to reflect a general change in conditions in the Baltic Sea history; the apparent discrepancy between the littoral and off-shore records may be due to differential response to the change by the littoral and off-shore diatom assemblages.
\end{abstract}

Key words: Baltic Sea history, diatom stratigraphy, Mastogloia stage, Litorina Sea, Ancylus Lake, Clypeus limit, sea-level changes, Flandrian, Finland.

Hannu Hyvärinen: Department of Geology, Division of Geology and Palaeontology, University of Helsinki, Snellmaninkatu 5, SF-00170 Helsinki 17, Finland.

\section{Introduction}

Recent summaries of Baltic Sea history (e.g. in Gudelis \& Königsson 1979) generally recognize a transition stage of low salinity, called the Mastogloia Sea, between the lacustrine Ancylus Lake stage and the brackish Litorina Sea stage. It is based on diatom investigations in Sweden and Finland of sediments deposited in the nearshore waters of the ancient Baltic. The Mastogloia strata are usually dominated by fresh-water (mainly oligohalobous) diatom assemblages similar to those found in Ancylus strata. They are distinguished, however, by the presence of a sparse, weakly brackish (oligohalobous to mesohalobous, euryhaline) component that contains species such as Rhoicosphenia curvata, Nitzschia tryblionella, Campylodiscus echeneis and $C$. clypeus, in addition to the type genus Mastogloia. All these taxa are common in the littoral of the subsequent Litorina Sea stage and the present Baltic. They make their first ap- 
pearance around 8500 B.P. in sequences from southern Sweden (Berglund 1964) and around 8000 B.P. on the Finnish side of the Baltic (Alhonen 1971, Eronen 1974). A more pronounced increase in saline diatoms takes place around or shortly after 7500 B.P., marking the beginning of the Litorina Sea proper (Litorina in a strict sense). In terms of Baltic development, the Mastogloia episode has been taken to reflect a gradual penetration of the Baltic basin by salt water after the opening of the Danish straits as a result of the eustatic rise in the level of the ocean. According to this interpretation, the Mastogloia Sea should be considered, in agreement with Munthe (1940), an initial stage of the Litorina Sea in a broad sense.

On the other hand, no transitional unit corresponding to the littoral Mastogloia stage has been observed in deep-water sediments. According to Ignatius et al. (1981), the Ancylus and Litorina strata are separated in Baltic off-shore cores by a sharp lithostratigraphic boundary dated at about 7500 B.P. This boundary »is generally so sharp that a catastrophic event in the hydrographic conditions of the entire Baltic Sea seems to be the only plausible explanation» (Ignatius et al. 1981, p. 63). Hence, in view of the off-shore evidence, these authors prefer to drop the Mastogloia stage altogether and to prolong the Ancylus Lake stage to about 7500 B.P. They point out that many weakly brackish diatoms, including Mastogloia spp., »are also known from fresh-water littoral environment in proximity to carbonate sediments and limestone bedrock» ( $c f$. e.g. Mölder \& Tynni 1973). The Mastogloia diatom complex would then be just a local, trophic variant of the littoral floras of the Ancylus Lake.

This paper discusses observations from the Helsinki area. Sample cores are available from a number of small lake basins formerly connected with the Baltic and containing sediments deposited at various depths within a broad nearshore environment over the transition from Ancylus to Litorina times. Comparison of data from the different sites indicates that between about 8000 and 7500 B.P. diatoms of the Mastogloia group commonly grew in the strictly littoral facies, whereas sublittoral sediments deposited at the same time in somewhat deeper water contain ordinary Ancylus floras with little or no admixture of brackish species. Irrespective of facies, no occurrences of the Mastogloia flora have been found in sediments older than 8000 B.P. Pre-Ancylus sediments are not considered here.

Fig. 1 shows the location of the stratigraphical sites investigated and the altitude and tilt of the highest limit of the Litorina Sea. The interval between 8000 and 7000 B.P. was a period of a nearly stable relative sea level in the present area, with an overall regression of less than two metres (Hyvärinen 1982). Hence, no distinction in altitude and trend can be made between an early brackish-water limit (Mastogloia limit) and the highest limit of the Litorina Sea in a strict sense. The limit shown here corresponds to the highest topographical occurrence of postAncylus brackish sediments and indicates the general position of the shoreline between about 8000 and 7000 B.P. For more details of the local shoreline displacement, see Alhonen et al. 1978, Hyvärinen 1979, 1980, 1982, and Eronen \& Haila 1982 .

Most of the stratigraphical data used here have been published in the papers mentioned above. In addition to the previous sites, there are three new sites, for which pollen and diatom diagrams are appended. The sediment cores were collected with a piston sampler from lake ice during the winters of 1981-1983. The samples were processed by standard methods. The diatom precentages are based on counts of between 200 and 500 valves per slide, the basic sum comprising all taxa. The taxonomy and nomenclature are in accordance with Mölder \& Tynni 1967-1973 and Tynni 1975-1980. The pollen diagrams have been divided into regional pollen assemblage zones identified in southwestern Finland (Donner 1971); these zones are 


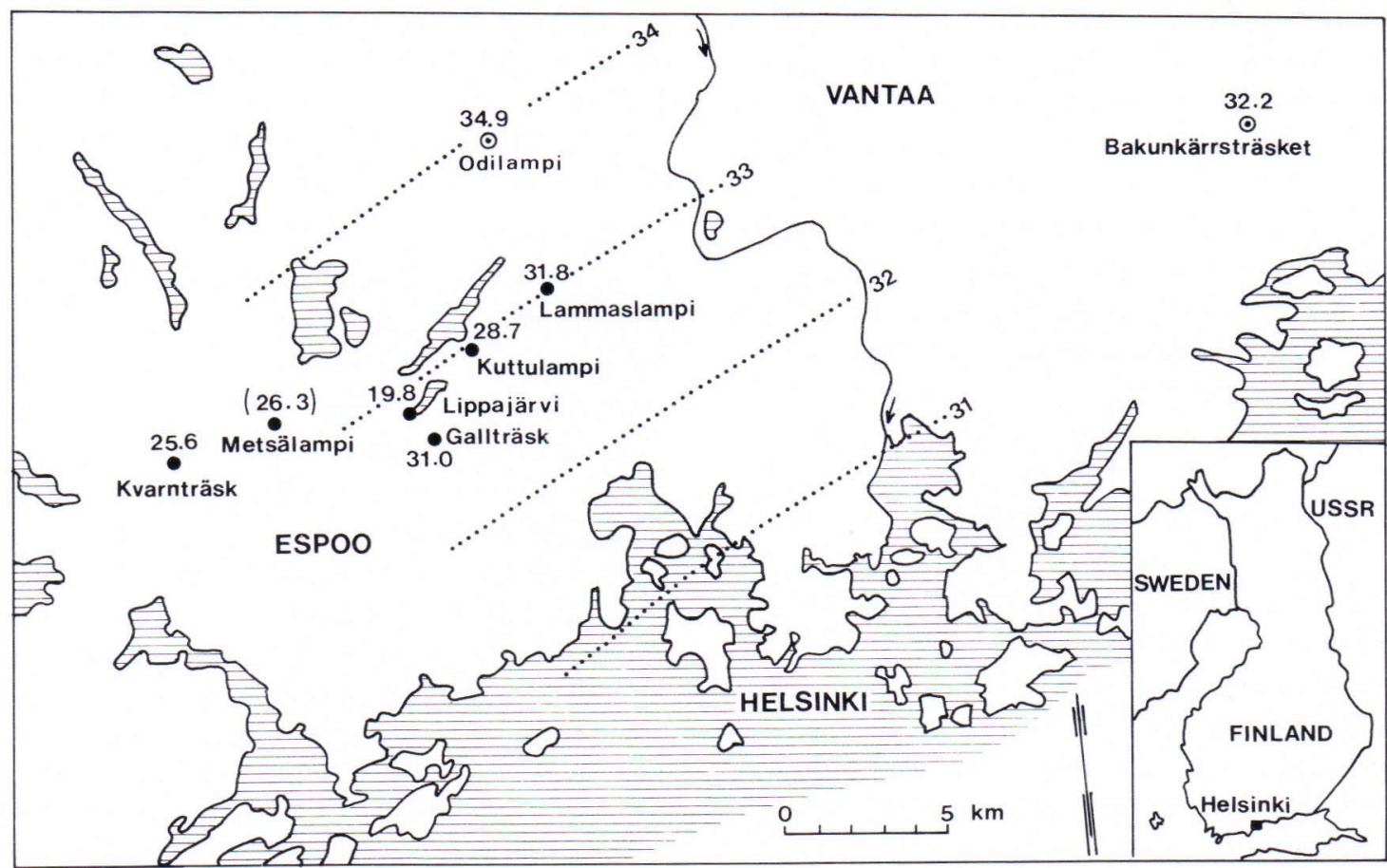

- Site below Litorina limit

○ Site at or above Litorina limit

..$^{\circ}$ Litorina isobase

Fig. 1. Map of the Helsinki area, showing the stratigraphical sites used and the isobases for the highest Litorina shoreline. The figures are metres above the present sea level.

used in the discussion. The radiocarbon datings were carried out by the Radiocarbon Dating Laboratory of Helsinki. All ages are given in conventional, uncorrected radiocarbon years B.P.

The sequences were correlated on the basis of radiocarbon and pollen data. The rational limit of Tilia $\left(\mathrm{T}^{\circ}\right)$ forms a particularly useful reference level because it falls within the critical interval close to the beginning of the Litorina period. Its local radiocarbon age is approximately 7400 B.P. (Fig. 2). In southern Finland in general, the Tilia limit is highly diachronous and often difficult to determine accurately because of the sparse representation of the species (Aartolahti 1967, Tolonen \& Ruuhijärvi 1976). It seems safe to use this horizon as a synchronous stratigraphical marker in the present con-

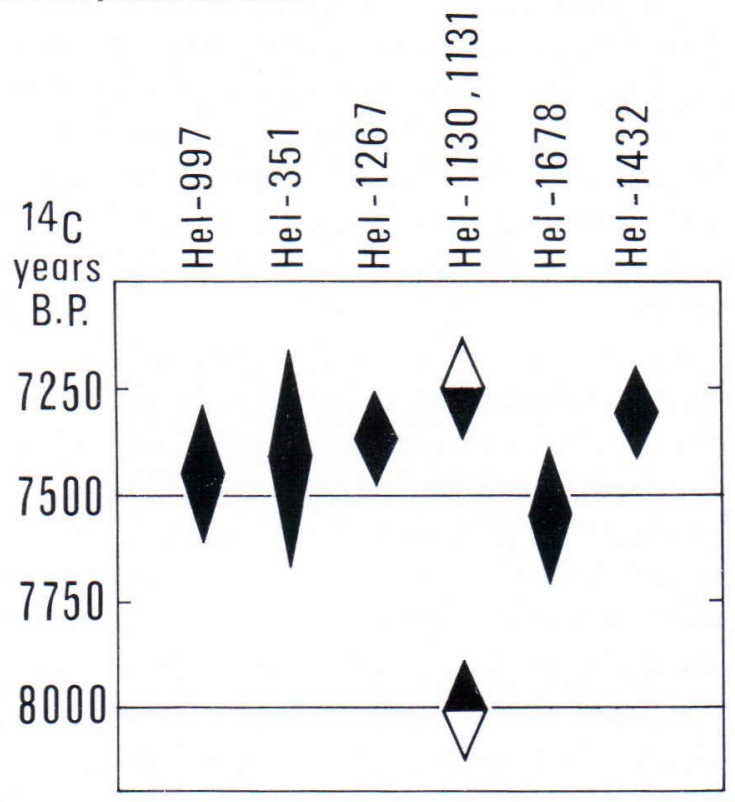

Fig. 2. Radiocarbon dates $( \pm 1 \sigma)$ for the Tilia pollen limit $\left(\mathrm{T}^{\circ}\right)$ from six sites near Helsinki. The black-and-white symbols denote dates from just above and below the limit. 
text, however, as the sites are close to one another and the samples have been prepared and counted by similar methods. This assumption is supported by the available radiocarbon data, but the dates alone would not have allowed a close enough correlation because of the margins of error they contain.

The discussion of the data as a whole is preceded by brief descriptions of and comments on the individual sites.

\section{Site descriptions and comments}

Odilampi (Hyvärinen 1980), alt. 34.9 m, size $3 \mathrm{ha}$, depth at coring site $2 \mathrm{~m}$, core length $8.3 \mathrm{~m}$. Stratigraphy: 0-370 cm, dark-brown gyttja; $370-600 \mathrm{~cm}$, greenish-brown gyttja, 600-720 $\mathrm{cm}$, pale, greenish clay-gyttja and gyttja-clay; $720-830 \mathrm{~cm}$, massive, grey silty-clay with dark streaks of sulphide. Isolation from the Baltic (introduction of small-lake diatoms): 585-600 $\mathrm{cm}(8010 \pm 120$, Hel-1266); Tilia pollen limit: $495-510 \mathrm{~cm}(7370 \pm 110$, Hel-1267).

The basin is just above the Litorina limit. The sediments below the isolation contact contain oligohalobous floras characteristic of the Ancylus Lake stage (Melosira islandica ssp. helvetica, M. arenaria, Stephanodiscus astraea and Gyrosigma attenuatum), with an increase in Epithemia spp., Surirella spp. and Fragilaria spp. towards the isolation contact.

A number of sequences from basins isolated from the Baltic in Ancylus times before 8000 B.P. have been investigated from areas nearby (Eronen \& Haila 1982, Glückert \& Ristaniemi 1982). As at Odilampi, these sequences only contain diatom assemblages usually associated with Ancylus sediments.

Bakunkärrsträsket (Hyvärinen 1979), alt. $32.2 \mathrm{~m}$, size $2 \mathrm{ha}$, depth at coring site $3 \mathrm{~m}$, core length $5.5 \mathrm{~m}$. Stratigraphy: $0-300 \mathrm{~cm}$, darkbrown gyttja; $300-350 \mathrm{~cm}$, greenish-brown gyttja with grey, silty bands in the middle of the section; $350-420 \mathrm{~cm}$, greenish-grey clay-gyttja and gyttja-clay; $420-550 \mathrm{~cm}$, massive, grey silt and clay with dark streaks of sulphide. Introduction of brackish diatoms: $345-355 \mathrm{~cm}$ $(8010 \pm 120$, Hel-1130); Tilia pollen limit: ca. $335 \mathrm{~cm}$; isolation from the Baltic: $305-315 \mathrm{~cm}$ $(7250 \pm 120$, Hel-1131).

The basin threshold is very close to the Litorina limit and the basin apparently had only a narrow and discontinuous connexion with the Baltic between 8000 and 7200 B.P. The sediments deposited during this interval contain highly variable amounts of brackish-littoral diatoms (max. $50 \%$ of the total flora), with Campylodiscus clypeus, Mastogloia spp., Nitzschia scalaris, Surirella striatula and Anomoeoneis sphaerophora as the most important species. Ordinary Ancylus assemblages are found in the silty sediments below the brackish strata.

Lammaslampi (Alhonen et al. 1978), alt. $31.8 \mathrm{~m}$, size $6 \mathrm{ha}$, depth at coring site $3 \mathrm{~m}$, core length $5.2 \mathrm{~m}$. Stratigraphy (the original paper gives depths below water level; the present paper gives depths below the sediment surface, as in the other sites): $0-300 \mathrm{~cm}$, gyttja; 300-320 $\mathrm{cm}$, clay-gyttja; $320-400 \mathrm{~cm}$, gyttja; $400-480$ $\mathrm{cm}$, clay-gyttja; $480-520 \mathrm{~cm}$, clayey-silt. Introduction of brackish diatoms: slightly below the dated level of $360-370 \mathrm{~cm}(7740 \pm 170$, Hel-996); Tilia pollen limit: $330-340 \mathrm{~cm}$ $(7450 \pm 160, \mathrm{Hel}-997)$; isolation from the Baltic: $280-290 \mathrm{~cm}(6550 \pm 170$, Hel-999).

The strata between $340 \mathrm{~cm}$ (Tilia limit) and $390 \mathrm{~cm}$ contain a sparse brackish flora $(5-10 \%$ of total diatoms), with Mastogloia smithii as the most constant species; Nitzschia tryblionella, $N$. scalaris, Rhoicosphenia curvata and Campylodiscus echeneis are also present. The proportion of brackish diatoms increases up to $70 \%$ of the total flora at $330-340 \mathrm{~cm}$. The dominant species are Campylodiscus clypeus, Nitzschia scalaris and Surirella striatula, indicating a brackish lagoon stage before the final isolation of the basin from the Baltic. The basin threshold is only $1-1.5 \mathrm{~m}$ below the Litorina limit. 


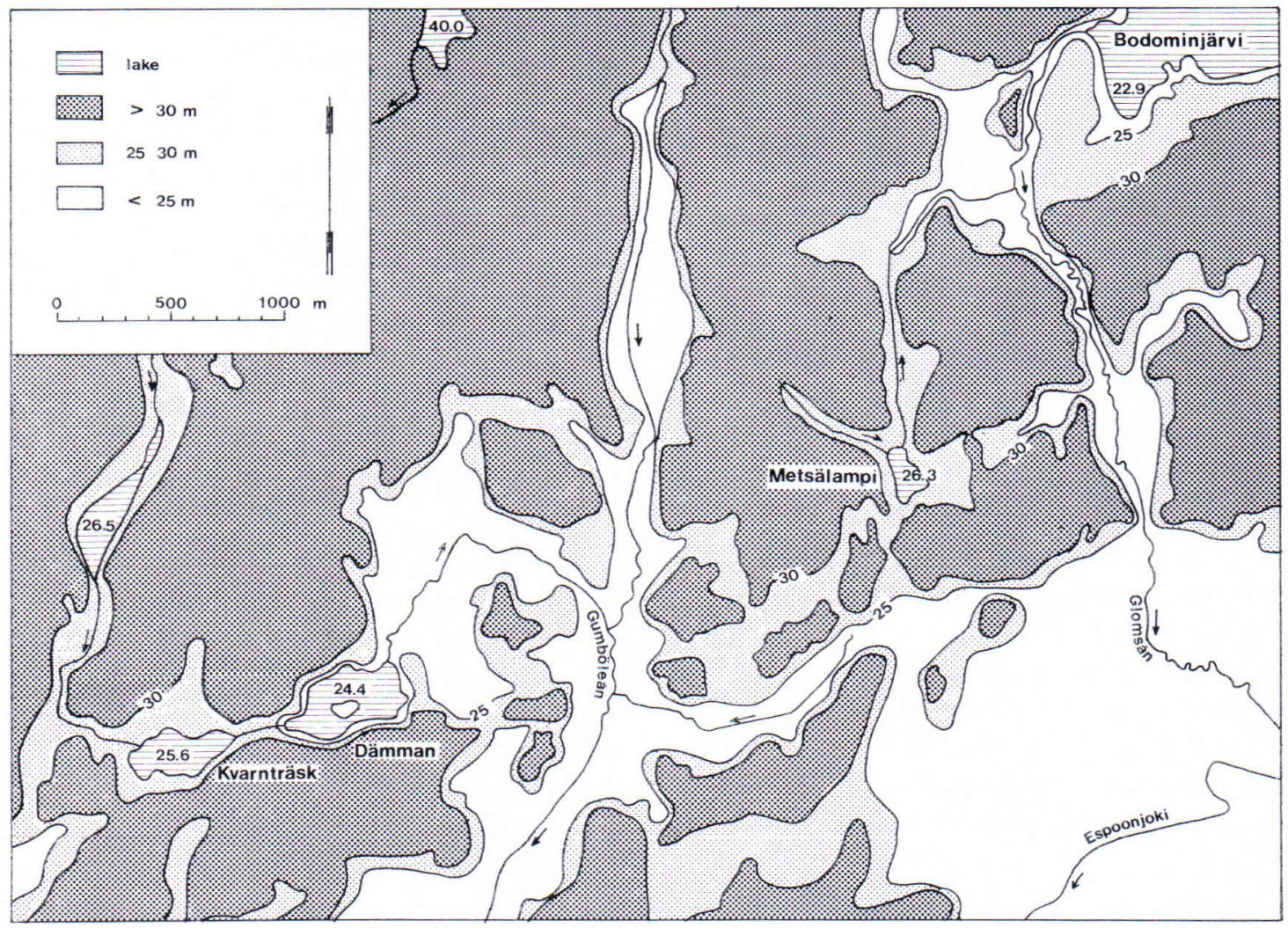

Fig. 3. General topography of the area around the Kvarnträsk and Metsälampi sites.

Metsälampi (new site, App. I), alt. $26.3 \mathrm{~m}$, size 3.5 ha, depth at coring site $2 \mathrm{~m}$, core length $7 \mathrm{~m}$. Stratigraphy: $0-350 \mathrm{~cm}$, dark-brown to greenish-brown gyttja; $350-420 \mathrm{~cm}$, greenishbrown, laminated gyttja in places stained with sulphide; $420-530 \mathrm{~cm}$, greenish-grey, laminated clay-gyttja, irregularly stained with sulphide; $530-615 \mathrm{~cm}$, massive, greenish-grey clay-gyttja and gyttja-clay, stained with sulphide, pebbles at $615 \mathrm{~cm} ; 615-700 \mathrm{~cm}$, massive, grey to pinkishgrey clayey-silt, sulphide streaks in the upper part. Appearance of brackish diatoms: ca. 545 $\mathrm{cm}$; Tilia pollen limit: $465-475 \mathrm{~cm}(7550 \pm$ 160, Hel-1678); isolation from the Baltic: 350 $-360 \mathrm{~cm}(6110 \pm 120$, Hel-1669).

Compared with the dates from the adjacent sites, the date obtained for the isolation of Metsälampi appears almost 1000 years earlier than would be expected from the altitude of its present threshold $(26.3 \mathrm{~m})$. The basin was probably already biologically isolated when the level of the Baltic stood at about 29 to $30 \mathrm{~m}$. The lowest thresholds south of the basin (Fig. 3) are only just below $30 \mathrm{~m}$, and the remaining sea-connexion via north is so narrow relative to its length of about $3 \mathrm{~km}$ that its influence must have been negligible; besides, its base may have been eroded somewhat below the original level during the existence of the present outlet. The highest Litorina limit near the site is between 33 and $34 \mathrm{~m}$. At that time the basin was part of a system of shallow coastal channels separated by islands from an open Baltic bay.

The pollen diagram reveals a marked discontinuity in the lower part of the core. Continuous succession starts from about the $615 \mathrm{~cm}$ level 
during the Pine Zone. This zone is directly underlain by strata containing a clearly older, lateWeichselian pollen flora (Artemisia assemblage), and the first Flandrian pollen unit (Birch Zone) is lacking. The basal strata were either deposited in Younger Dryas times or they consist of redeposited late-Weichselian sediments. The latter alternative is suggested by the absence of any of the varved structures normally found in primary sediments of that age deposited distally from the ice margin. In any case, there is no record of early Ancylus or Yoldia deposits from between 9000 and 10,000 B.P. At that time the site belonged to an open coastal zone exposed to wave action and currents, and the depth of the water varied between 50 and $30 \mathrm{~m}$. Non-deposition and erosion of sediments would be expected in this environment. Peaceful conditions favourable for continuous sedimentation were only established between 9000 and 8500 B.P. when the water level dropped from the Ancylus maximum at about $60 \mathrm{~m}$ to close to the Litorina limit.

The first indicators of salinity in the diatoms appear in the lower part of the Birch-alderhazel-elm Zone below the Tilia limit. At this stage the saline component, which accounts for up to $50 \%$ of the total flora, consists entirely of weakly brackish, littoral species. A successive increase in the brackish species leads to a more diverse flora dominated by Melosira moniliformis and $M$. westii, and including some planktic forms proper (Thalassiosira baltica, Coscinodiscus lacustris). An inverse succession, here somewhat obscured by the rapid rise of Fragilaria spp., occurs near the isolation level.

Kuttulampi (Hyvärinen 1982), alt. $28.7 \mathrm{~m}$, size $0.8 \mathrm{ha}$, depth at coring site $0.5 \mathrm{~m}$, length of core $7.6 \mathrm{~m}$. Stratigraphy: $0-70 \mathrm{~cm}$, disturbed, silty layer; $70-370 \mathrm{~cm}$, dark-brown gyttja; 370 $-400 \mathrm{~cm}$, greenish-brown gyttja; $400-470 \mathrm{~cm}$, irregularly laminated, greenish-grey gyttja-clay; $470-570 \mathrm{~cm}$, greenish-brown clay-gyttja and gyttja-clay, laminated; $570-700 \mathrm{~cm}$, greenishgrey gyttja-clay, irregularly laminated, grading downwards into grey silt; $700-760 \mathrm{~cm}$, massive, grey silty-clay with dark streaks of sulphide. Appearance of saline diatoms: ca. $570 \mathrm{~cm}$; Tilia pollen limit: $530-540 \mathrm{~cm}(7310 \pm 110$, Hel-1432); isolation from the Baltic: $320-330$ $\mathrm{cm}(5700 \pm 120$, Hel-1435).

This is a very small basin that in Litorina times was a lagoon with a single, narrow connexion with the Baltic. The diatom flora throughout the brackish stage is therefore dominantly littoral. There is a gradual increase in both the abundance and number of species of saline diatoms in the lower half of the brackish sequence, followed by a decline towards the isolation level. The brackish sequence opens somewhat below the Tilia limit with a narrow, continuous tail of Mastogloia spp. (also sparse Nitzschia tryblionella and Rhoicosphenia curvata), after which first Campylodiscus clypeus and then a more diverse brackish flora appears.

Kvarnträsk (new site, App. II), alt. $25.6 \mathrm{~m}$, size 7 ha, depth at coring site $1 \mathrm{~m}$, core length $7 \mathrm{~m}$. Stratigraphy: $0-280 \mathrm{~cm}$, brown gyttja, upwards very loose and with coarse plant detritus; $280-320 \mathrm{~cm}$, greenish-brown gyttja and claygyttja; 320-460 cm, greenish-grey clay-gyttja; $460-515 \mathrm{~cm}$, greenish-grey gyttja-clay, finely laminated, partly stained with sulphide; $515-700 \mathrm{~cm}$, massive, grey silt and clay with sulphide streaks, interrupted by a more organic stratum at $570-580 \mathrm{~cm}$. Appearance of saline diatoms: ca. $500 \mathrm{~cm}$, Tilia pollen limit: ca. 500 $\mathrm{cm}$; isolation from the Baltic: ca. $280 \mathrm{~cm}$. No radiocarbon dates are available.

This is a relatively large basin with its threshold between 6 and $7 \mathrm{~m}$ below the Litorina limit. It was originally connected at both ends with the Baltic, but as the water level sank below the 30 $\mathrm{m}$ level only a single connecting inlet remained from a wider bay to the east of the basin (Fig. 3 ). The water was over $10 \mathrm{~m}$ deep during the formation of the Litorina limit.

The pollen stratigraphy shows a complete sequence from late Pine Zone times to close to the present time (note Cerealia curve near the top). 
The main chronological markers are the Tilia limit (ca. 7400 B.P.) and the Picea limit (35004000 B.P.). The appearance of saline diatoms is rather abrupt, coinciding with the Tilia limit and with the transition from the basal silts to the laminated clay-gyttja. The brackish section opens with a prominent peak of Mastogloia spp., with some Campylodiscus clypeus and $C$. echeneis, and followed by Melosira westii, $M$. moniliformis and Nitzschia sigma in sequence. Towards the isolation level these again give way first to Navicula peregrina, Amphora commutata and Tropidoneis dannfeltii and finally to Nitzschia scalaris, N. circumsuta and Anomoeoneis sphaerophora. Below the Tilia limit, a typical Ancylus flora is found, with only a trace of Mastogloia and Rhoicosphenia.

Lippajärvi (new site, App. III), alt. $19.8 \mathrm{~m}$, size 57 ha, depth at coring site near the SW end of the lake $1.5 \mathrm{~m}$ (the main basin has a maximum depth of $4.5 \mathrm{~m}$ ), length of core $5 \mathrm{~m}$. Stratigraphy: $0-150 \mathrm{~cm}$, brown gyttja; $150-380 \mathrm{~cm}$, brownish-green clay-gyttja with a few sandy bands in the lower part; 380-420 cm, grey sandy-silt; $430-500 \mathrm{~cm}$, massive, grey to brownish-grey clayey-silt with dark streaks of sulphide. Appearance of saline diatoms: ca. $380 \mathrm{~cm}$; Tilia pollen limit: $\mathbf{3 7 0}-\mathbf{3 8 0} \mathrm{cm}$; isolation from the Baltic: $150-160 \mathrm{~cm}$. No radiocarbon dates are available.

This is by far the largest basin studied, with its threshold about $13 \mathrm{~m}$ below the Litorina limit. Together with the neighbouring basin of Pitkäjärvi to the northwest it is part of a tectonic depression that in Litorina times was a major Baltic inlet up to two kilometres wide. The depth of water at the core site was $17-18 \mathrm{~m}$ at the beginning of the Litorina period.

The basal part of the core, deposited before the beginning of the Birch-alder-hazel-elm Zone, shows signs of redeposition and erosion (cf. Metsälampi). The Pine Zone is lacking, and even the early portion of the $\mathrm{B}-\mathrm{a}-\mathrm{h}-\mathrm{e}$ Zone below the Tilia limit may be incomplete. The basal silts are devoid of diatoms, but a well de- fined Ancylus flora is found from about $430 \mathrm{~cm}$ upwards; the presence of sand and the high percentages of Melosira arenaria suggest that some redeposition has occurred from a shallow facies near the beach. The brackish sequence opens with peaks of Campylodiscus echeneis and $C$. clypeus, contemporaneous with the appearance of Tilia, and immediately succeeded by Coscinodiscus lacustris (plankton), Melosira moniliformis, $M$. juergensi and Nitzschia sigma. These are replaced by prominent peaks of Nitzschia tryblionella and N. scalaris and a smaller peak of Campylodiscus echeneis near the isolation contact.

\section{Discussion}

Fig. 4 illustrates the stratigraphical distribution of saline diatoms (taxa associated with the brackish, post-Ancylus stages of the Baltic) in the sediments studied from the Helsinki area. The cores are arranged from right to left in order of diminishing altitude above the present sea level and increasing depth below the Litorina limit. The uppermost sites near the Litorina limit were only briefly connected with the Litorina Sea, but the lower sites experienced a longer brackish episode before they were successively cut off from the Baltic. The core sections spanning the Ancylus - Litorina transition are synchronized with reference to the $\mathrm{T}^{\circ}$ horizon. The sediments from that interval range from strictly littoral gyttjas and clay-gyttjas deposited at a depth of a few metres to gyttja-clays and silts deposited at depths between 10 and 20 metres.

It is obvious that the first indicators of salinity towards the beginning of the Litorina period appear at different times in different facies, the change in the shallow facies being earlier and more gradual than in deeper facies. Varying percentages of weakly brackish taxa are regularly included in the littoral, periphytic floras deposited in the uppermost basins immediately be- 


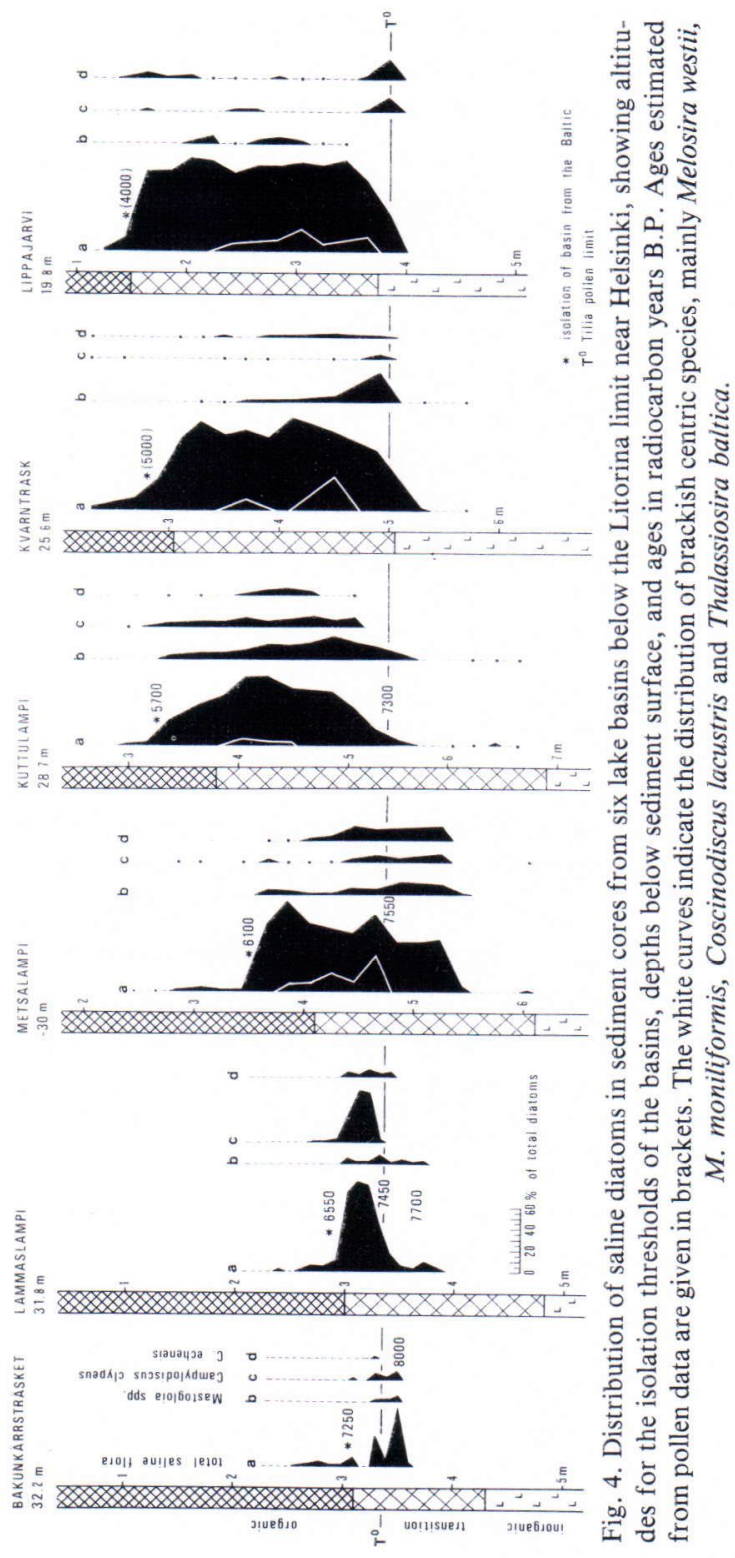

fore the $\mathrm{T}^{\circ}$ horizon between about 8000 and 7500 B.P. These floras would be referred to the Mastogloia stage. At the same time, typical Ancylus floras with abundant planktic diatoms were being deposited in deeper water at the lower sites. As these latter sites became shallower towards $\mathrm{T}^{\circ}$ times they were invaded by brackish-littoral diatoms of the Mastogloia group.

A richer brackish flora characteristic of Litorina sediments proper appears after the $\mathrm{T}^{\circ}$ level in the basins that retained their contact with the Baltic. A series of taxa regularly absent from the earlier levels is introduced, including a few brackish-planktic forms, and the total amount of brackish diatoms tends to rise. These diatom trends contrast with the local trend of progressive shoaling at the sites $^{1}$ and must therefore reflect a regional change towards fully brackish conditions. The appearance of the planktic component indicates that this change also involved the depeer facies outside the immediate sedimentation environments.

These results agree with the conclusions by Ignatius \& Tynni (1978) and Ignatius et al. (1981) that the Mastogloia stage is restricted to the littoral facies and that the only change traceable in the off-shore sediments and diatoms relates to the beginning of the Littorina stage proper around 7500 B.P. However, the Mastogloia floras cannot be adequately interpreted as reflecting local edaphic or bedrock conditions, because they occur quite regularly, irrespective of locality, after but not before a certain time point (in southern Finland after 8000 B.P.; in southern Sweden ca. 500 years earlier). This pattern of occurrence is more consistent with a general salinity rise in the area concerned. The apparent discrepancy between the shallow-water and deep-water diatom records may be due to a different reaction threshold of the littoral and planktic diatom assemblages. The latter comprise a relatively small number of taxa and may therefore be expected to be less sensitive to slight environmental changes than the more diverse littoral assemblages; on the other hand, they would be expected to show a more abrupt change once a critical thershold is reached. It is well known that both Melosira islandica ssp.

\footnotetext{
${ }^{1}$ It can be demonstrated that no significant fluctuations in the relative sea level occurred in this area during early Litorina times (Hyvärinen 1980, 1982).
} 
helvetica and Stephanodiscus astraea, the main components of the Ancylus Lake plankton, can also grow in weakly brackish water (e.g. Mölder \& Tynni 1967, 1968, Hustedt 1933). The same holds true for Melosira arenaria, which is commonly found in small amounts in Litorina sediments, for instance at the present sites. Thus, the abundance of these species in many sediments dating from Mastogloia times is not incompatible with the concept of a weakly saline stage.

Nevertheless, as stressed by Ignatius et al. (1981), the lithological and biostratigraphical change around 7500 B.P. is so marked, particularly in the off-shore facies, that it would seem to represent a discrete event in the Baltic hydrography, rather than just a gradual salinity change. Eronen (1974, Donner \& Eronen 1981) has suggested that the dense oceanic water entering the Baltic basin remained initially, in Mastogloia times, in the deep, near-bottom layers and was mixed with the surface water to a limited degree only; at a certain point, when the saline influx from the ocean had become sufficiently large, an overall mixing in the Baltic water mass occurred, resulting in a rapid establishment of fully brackish conditions.

The existence of an ocean connexion since well before the beginning of the Litorina stage proper is supported by independent evidence of shoreline displacement. Emergence curves based on recent investigations are available from widely separate areas in Finland: the south coast (Hyvärinen 1980, Eronen \& Haila 1982), southern Ostrobothnia (Salomaa 1982), and an area north of the Gulf of Bothnia (Saarnisto 1981). Despite differences due to the increasing isostatic uplift northwards, all these curves show a marked retardation in the rate of emergence between 8000 and 8500 B.P. The rapid emergence immediately after 9000 B.P. is mainly due to isostatic rebound and to a lesser extent to the drop in the level of the Ancylus Lake; the apparently parallel retardation in the separate areas that follows is best explained as a result of the introduction of the eustatic component as the Baltic basin resumed contact with the ocean (cf. Hyvärinen 1980, Saarnisto 1981).

Many uncertainties are associated with the history of the Ancylus Lake, and these are naturally reflected in the interpretation of the subsequent stages as well. The traditional picture of the events around the proposed outlet of the Ancylus Lake in central Sweden has recently been questioned in the light of fresh investigations. However, no consistent, new picture has yet emerged. The situation has been reviewed on several occasions by Fredén (e.g. 1979). In his opinion, the available data suggest that the Baltic waterbody was not dammed up above the ocean level during the Ancylus period, although the influx of salt water was obstructed at times; hence, this stage might more appropriately be called the Ancylus Sea. The concept of an Ancylus Sea would fit in well with the absence of a clear-cut stratigraphical and biological limit between Ancylus and Mastogloia strata and with the time-transgressive character of the transition; it would, however, fit in less well with the shoreline displacement trends discussed above.

\section{Note on the term »Clypeus limit»}

This term, derived from Campylodiscus clypeus, is restricted to Sweden and Finland. The subject of much discussion during the early decades of the century, it has recently been used in two senses:

1) To denote the highest topographical occurrence of brackish Baltic sediments postdating the Ancylus strata. In other words, it is the limit up to which the terrain was submerged by brackish water. In this sense, the Clypeus limit is practically equivalent to the highest Litorina shoreline, and the latter is frequently defined by reference to the former. The name refers to the common occurrence of $C$. clypeus in the lit- 
toral, shallow-water deposits that usually define the upper limit of the submergence.

2) To denote a stratigraphical horizon marking the beginning of the Litorina stage in a strict sense (the Mastogloia/Litorina limit). This stratigraphical use of the term is common in Finland (for recent examples, see Eronen 1974, Hyvärinen 1980, Donner \& Eronen 1981), but to my knowledge is less common, or less explicit, in Sweden.

In the former sense (1), the Clypeus limit, or the highest brackish water limit, is a complex feature, whose formation was a function of both shoreline displacement and the spread of salinity in the Baltic basin. In areas of slow isostatic uplift, where the relative sea level was transgressive or stable in early Litorina times, the topographical brackish-water limit postdates the first stratigraphical occurrence of brackish-water sediments (see p. 100 for conditions in the Helsinki area). In areas of continuous emergence farther north, the topographical limit is contemporaneous with the introduction of brackish conditions. On the other hand, in the north the spread of salinity was delayed compared with the more central parts of the Baltic. The topographical Clypeus limit may therefore be said to be time-transgressive $\gg$ in two ways» (Eronen 1974, p. 138). In practise, the opposite age trends in the Clypeus limit seem to cancel each other out to some extent, so that in many areas the observed limit is associated with the early phases of the Litorina Sea.

\section{References}

Aartolahti, T., 1967. Zur rationellen Tilia-Pollengrenze $\left(\mathrm{T}^{\circ}\right)$ in Finnland. Fennia 97: 1, 30 pp.

Alhonen, P., 1971. The stages of the Baltic Sea as indicated by the diatom stratigraphy. Acta Bot. Fennica 92, $1-18$.
The use of the term in the latter sense (2) implies that $C$. clypeus is a distinctive Litorina species, whose appearance (or proliferation) is related to the salinity rise at the onset of the Litorina stage proper; in this sense, the "Clypeus flora» and the "Mastogloia flora» are often contrasted as floras of different salinity demands and, hence, of different age. It is true that $C$. clypeus tends to peak later than, say, Mastogloia spp. in normal sediment successions, because it grows optimally in the strictly littoral (lagoon) facies. However, as demonstrated by the present data, for instance, it is not restricted to Litorina strata, as opposed to Mastogloia strata, but occurs commonly in both (cf. »Mastogloia-Clypeus Sea» by Munthe, 1940).

I find the stratigraphical use of the term potentially confusing, because it gives a false impression of the stratigraphical range and significance of $C$. clypeus and its associated flora. I suggest that the term should only be used in its original sense, to refer to a topographical limit.

Acknowledgements. My sincere thanks are due to the participants in the Quaternary palaeontology courses, Department of Geology, University of Helsinki, 1978-1983, for their assistance in collecting the cores and in analysing the samples, Dr. M. Eronen, Mr. H. Haila, Mr. R. Salomaa and Mr. T. Wallin for help in the field work, Mr. H. Jungner for the radiocarbon dating, Prof. J. Donner and Prof. M. Saarnisto for useful comments on the manuscript, and Mrs. G. Häkli for checking the language.
Alhonen, P.; Eronen, M.; Nunez, M.; Salomaa, R. \& Uusinoka, $R$., 1978. A contribution to Holocene shore displacement and environmental development in Vantaa, south Finland: the stratigraphy of Lake Lammaslampi. Bull. Geol. Soc. Finland 50, 69-79.

Berglund, B., 1964. The Post-glacial shore displacement in eastern Blekinge, southeastern Sweden. A preliminary survey. Geol. Fören. Förh. 93, 625-652. 
Donner, J., 1971. Towards a stratigraphical division of the Finnish Quaternary. Comment. Phys.-Math. 41, 281 -305 .

Donner, J. \& Eronen, M., 1981. Stages of the Baltic Sea and Late Quaternary shoreline displacement in Finland. Excursion Guide, INQUA subcommission of shorelines of northwestern Europe. University of Helsinki, Department of Geology, Division of Geology and Palaeontology, Stencil No. 5, 53 pp.

Eronen, M., 1974. The history of the Litorina Sea and associated Holocene events. Comment. Phys.-Math. 44, 79-195.

Eronen, M. \& Haila, H., 1982. Shoreline displacement near Helsinki, southern Finland, during the Ancylus Lake stage. Ann. Acad. Sci. Fennicae A III. 134, 111-129.

Fredén C., 1979. The Quaternary history of the Baltic. The western part. In: V. Gudelius \& L.-K. Königsson (eds.), The Quaternary history of the Baltic, 59-74. Acta Univ. Ups. Symp. Univ. Ups. Ann. Quing. Cel. 1, Uppsala.

Glückert, G. \& Ristaniemi, O., 1982. The Ancylus transgression west of Helsinki, South Finland - A preliminary report. Ann. Acad. Sci. Fennicae A III. 134, 99-110.

Gudelius, V. \& Königsson, L.-K. (Eds.), 1979. The Quaternary history of the Baltic. Acta Univ. Ups. Symp. Univ. Ups. Ann. Quing. Cel. 1 Uppsala, 279 pp.

Hustedt, F., 1930-1966. Die Kieselalgen Deutschlands, Österreichs und der Schweiz mit Berücksichtigung der übrigen Länder Europas sowie der angrenzenden Meeresgebiete. In: Rabenhorst, L. (Ed.), KryptogamenFlora von Deutschland, Österreich und der Schweiz 7: $1-3$, Leipzig.

Hyvärinen, H., 1979. Helsingin seudun rannansiirtyminen Litorina-aikana Sipoosta tutkitun näytesarjan valossa. (Bakunkärrsträsket: a stratigraphical site relevant to the Litorina shore displacement near Helsinki.) Terra 91, 15-20.

—, 1980. Relative sea-level changes near Helsinki, southern Finland, during early Litorina times. Bull. Geol. Soc. Finland 52: 2, 207-219.
-, 1982. Interpretation of stratigraphical evidence of sealevel history: A Litorina site near Helsinki, southern Finland. Ann. Acad. Sci. Fennicae A III. 134, 139 -149 .

Ignatius, H. \& Tynni, R., 1978. Itämeren vaiheet ja piilevätutkimus. (Baltic Sea stages and diatom analysis.) Publications of the Department of Quaternary Geology, University of Turku, 36. Turku.

Ignatius, H.; Axberg, S.; Niemistö, L. \& Winterhalter, B., 1981. Quaternary Geology of the Baltic Sea. In: Voipio, A. (ed.), The Baltic Sea, 54-104. Elsevier, Amsterdam, Oxford, New York.

Munthe, H., 1940. Om Nordens, främst Baltikums, senkvartära utveckling och stenåldersbebyggelse. On the Late-Quaternary development and the Stone Age settlement of north Europe, primarily the Baltic. K. Sven. Vetenskapsakad. Handl. III 19: 1, 242 pp.

Mölder, K. \& Tynni, R., 1967-1973. Über Finnlands rezente und subfossile Diatomeen I-VII.-I, Bull. Comm. géol. Finlande 29, 199-207 (1967); II, Bull. Geol. Soc. Finland 40, 151-170 (1968); III, ibid. 41, 235-251 (1969); IV, ibid. 42, 129-144 (1970); V, ibid. 43, 203-220 (1971), VI, ibid. 44, 141-149 (1972); VII, ibid. 45, 159-179 (1973).

Saarnisto, M., 1981. Holocene emergence history and stratigraphy in the area north of the Gulf of Bothnia. Ann. Acad. Sci. Fennicae A III. 130, 42 pp.

Salomaa, R., 1982. Post-glacial shoreline displacement in the Lauhanvuori area, western Finland. Ann. Acad. Sci. Fennicae A III. 134, 81-97.

Tolonen, K. \& Ruuhijärvi, R., 1976. Standard pollen diagrams from the Salpausselkä region of southern Finland. Ann. Bot. Fennici 13, 155-196.

Tynni, R., 1975-1978. Über Finnlands rezente und subfossile Diatomeen VIII-XI.-VIII, Geol. Surv. Finland Bull. 274, 55 pp. (1975); IX, ibid. 284, 37 pp. (1976); X, ibid. 296, 55 pp. (1978); XI, ibid. 312, 93 pp. (1980).

Manuscript received, October 17, 1983. 




App. I A. Pollen diagram of Metsälampi. For sediment symbols, see App. I B. 


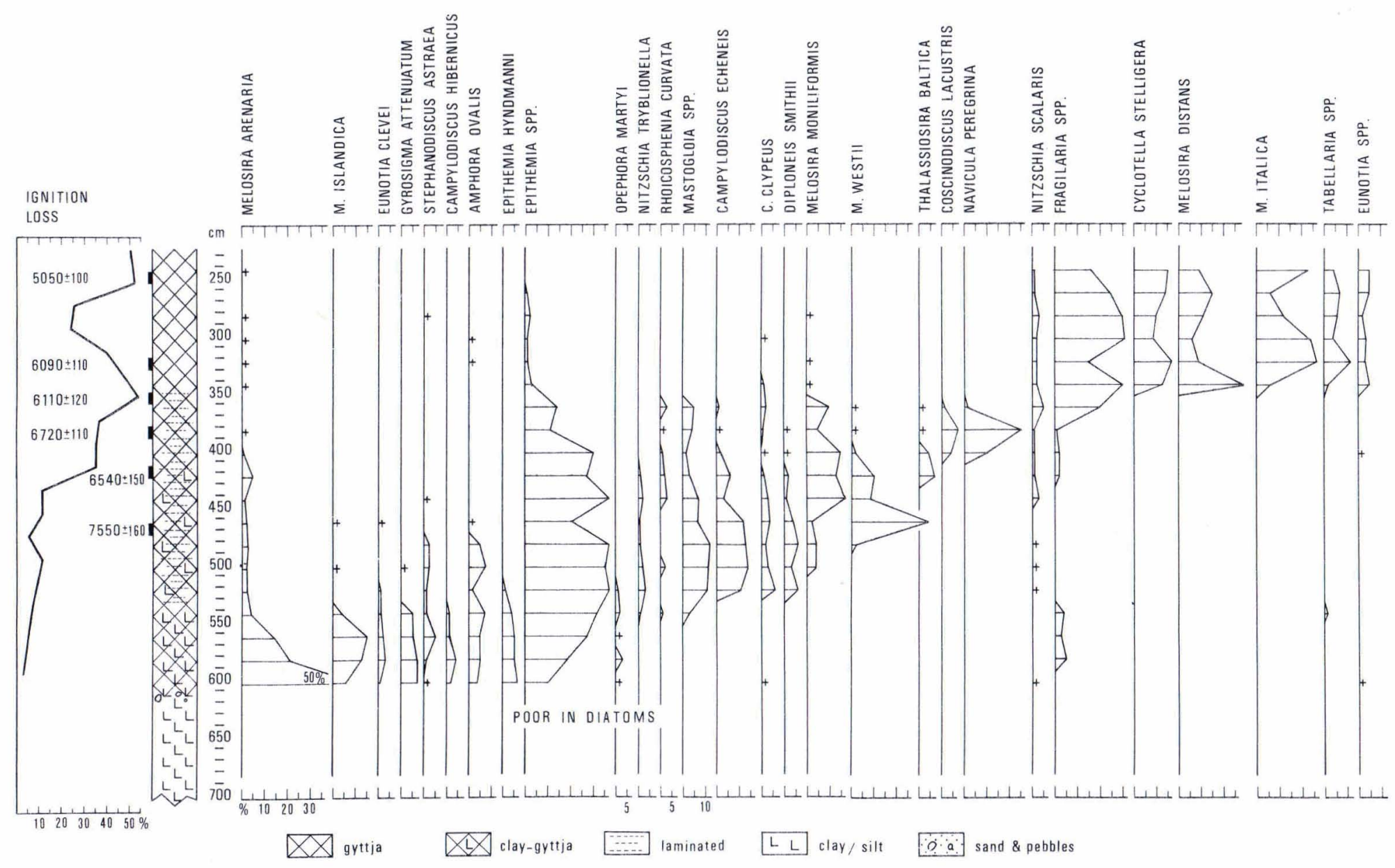

붕

App. I B. Diatom diagram of Metsälampi. Selected species. 


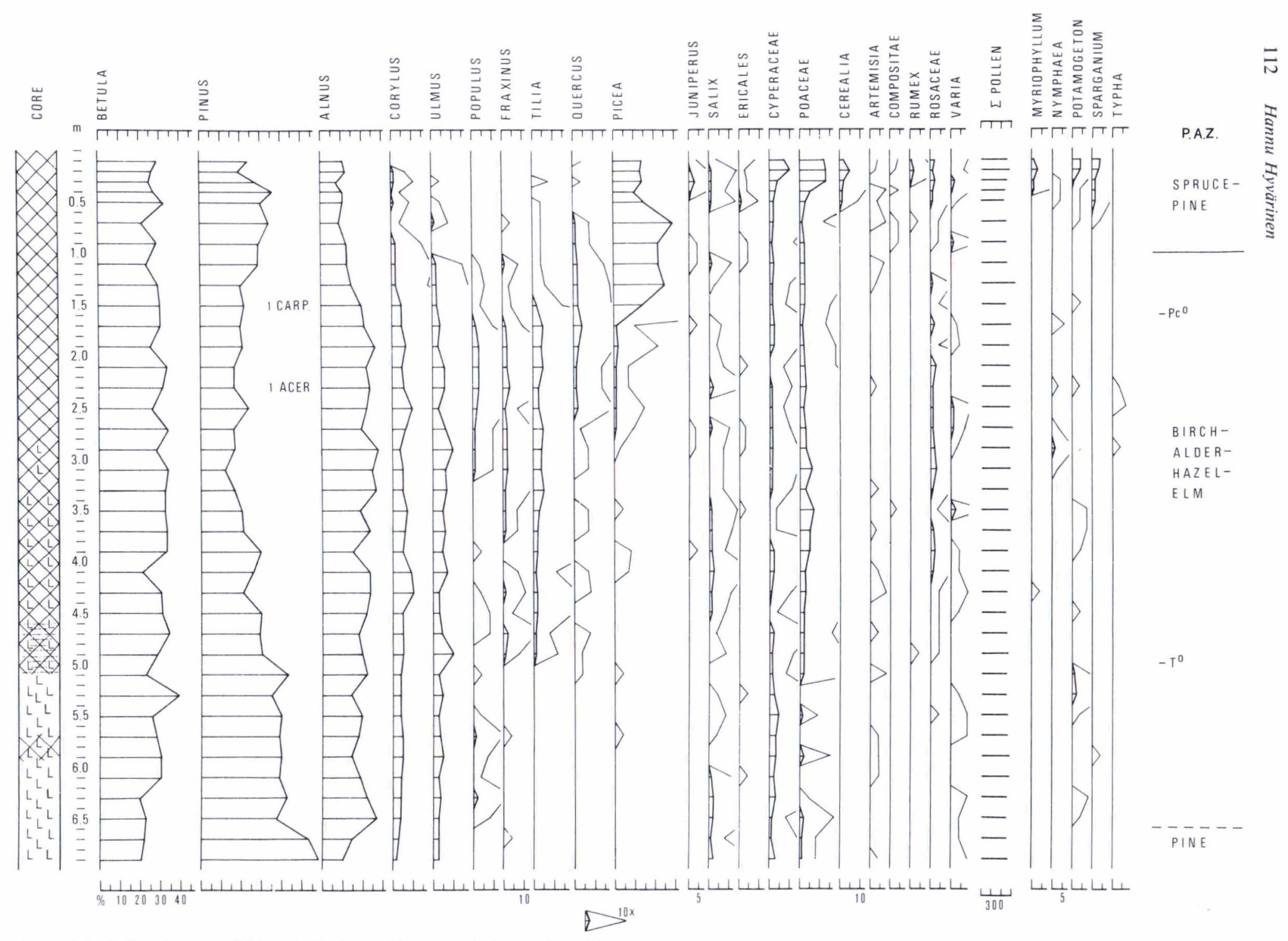

App. II A. Pollen diagram of Kvarnträsk. For sediment symbols, see App. I B. 


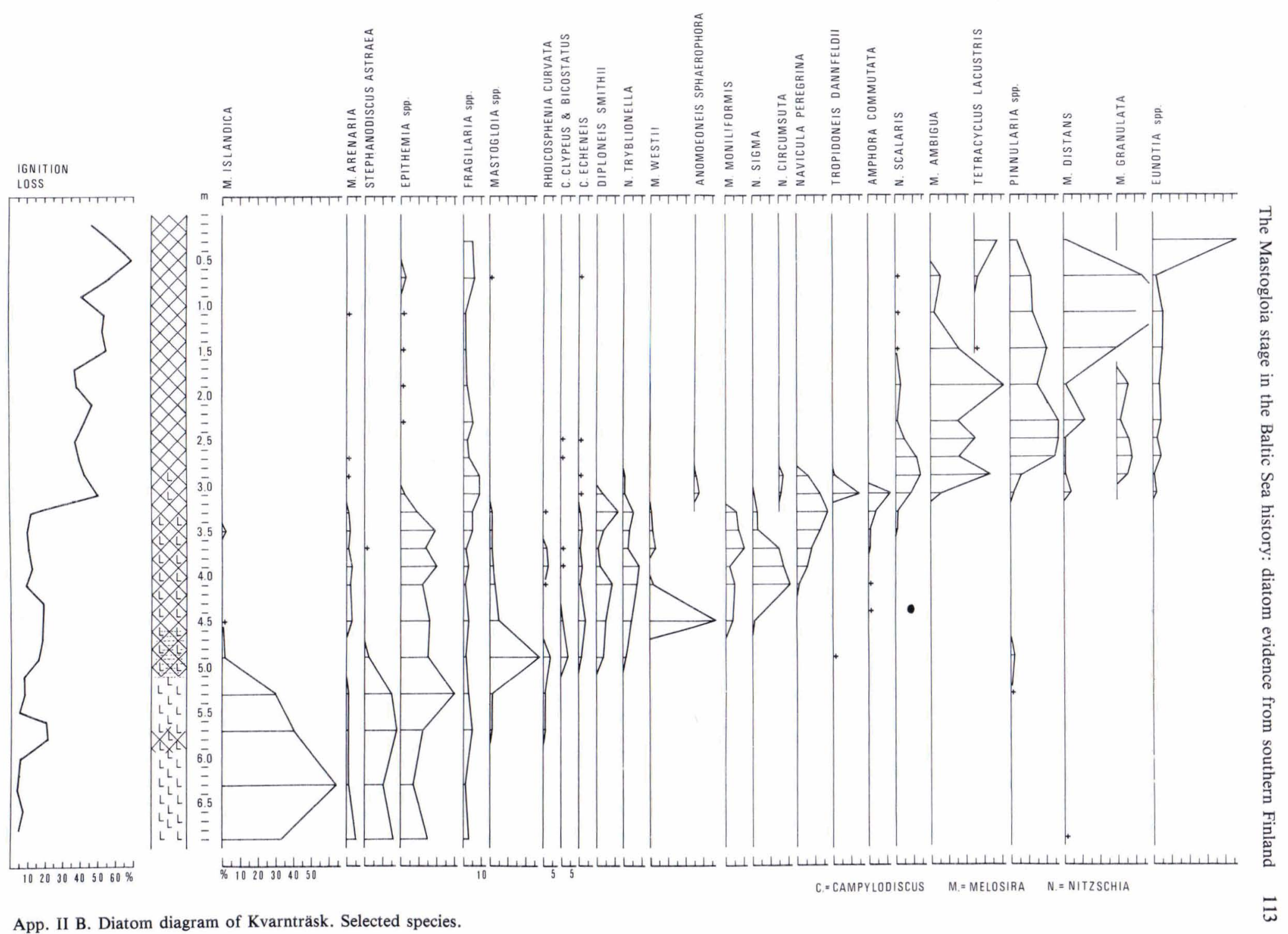




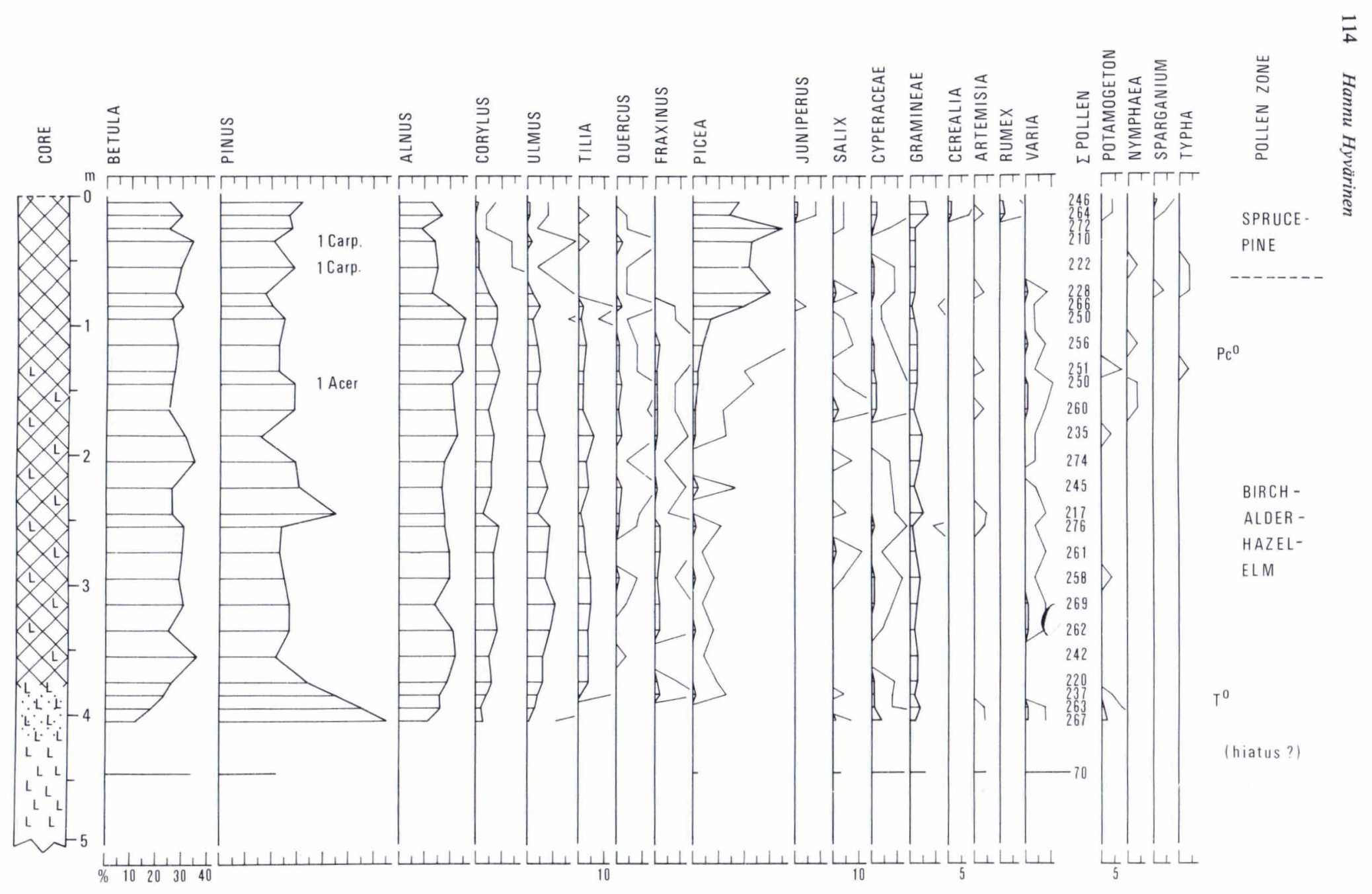

App. III A. Pollen diagram of Lippajärvi. For sediment symbols, see App. I B. 


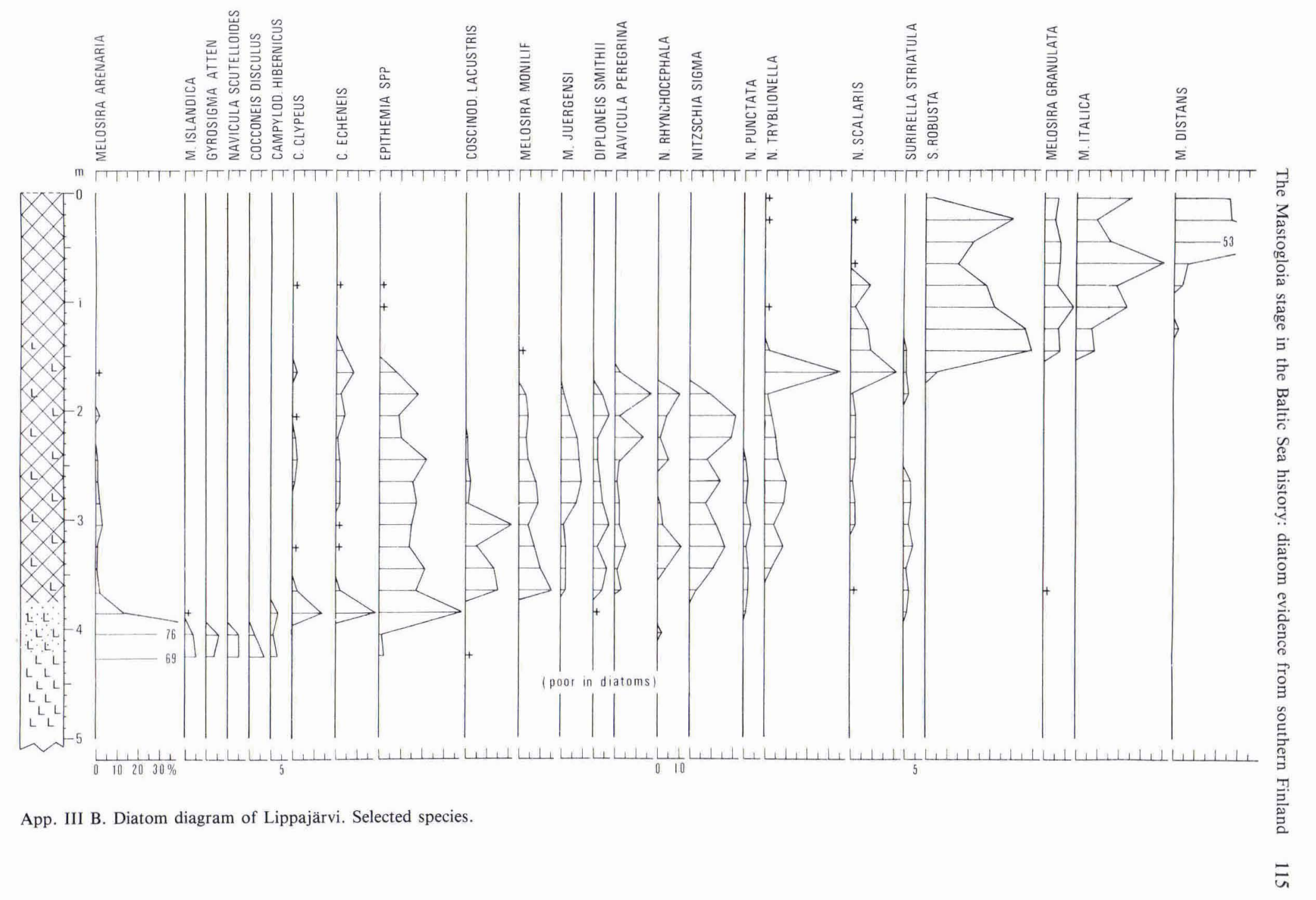

